Provided for non-commercial research and education use. Not for reproduction, distribution or commercial use.

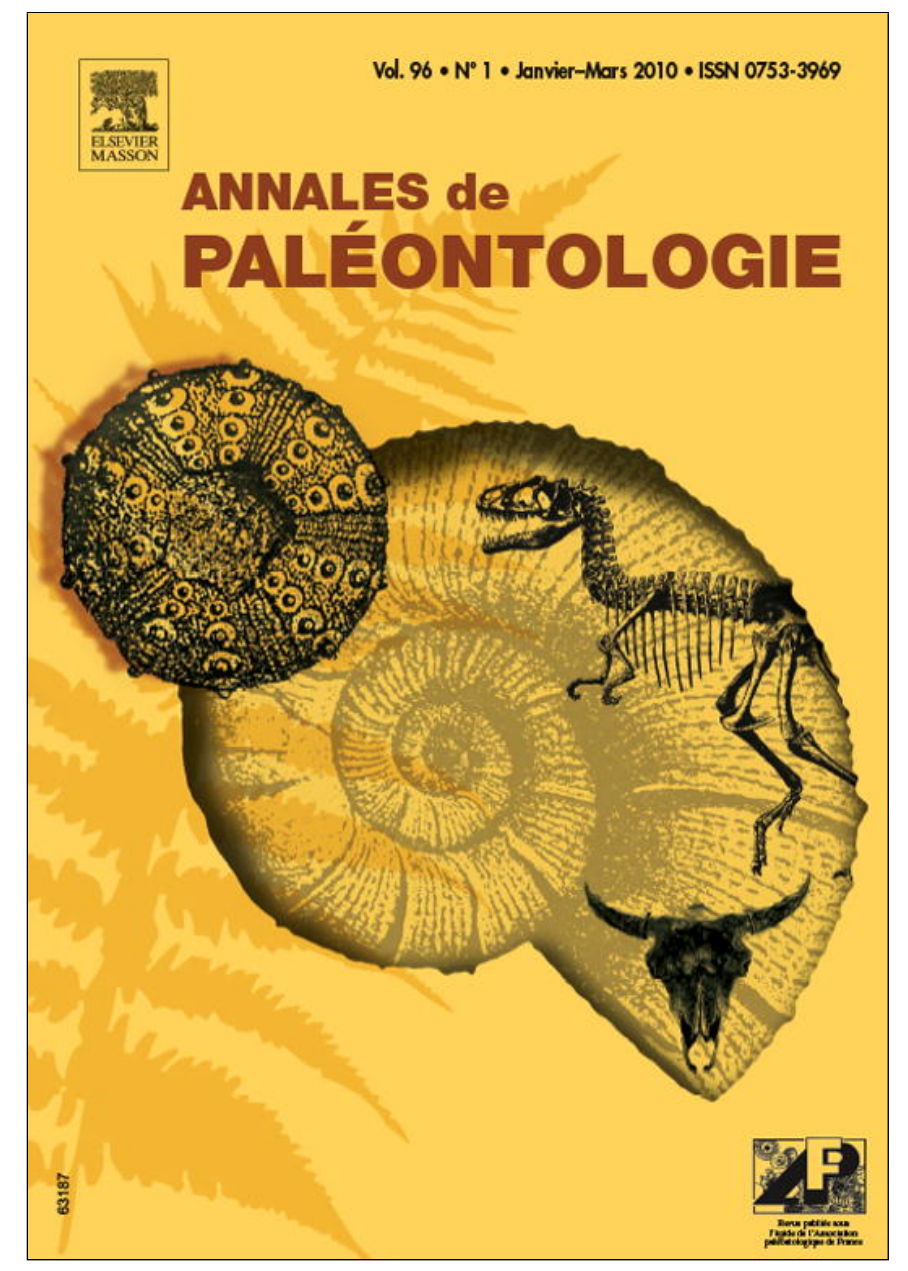

This article appeared in a journal published by Elsevier. The attached copy is furnished to the author for internal non-commercial research and education use, including for instruction at the authors institution and sharing with colleagues.

Other uses, including reproduction and distribution, or selling or licensing copies, or posting to personal, institutional or third party websites are prohibited.

In most cases authors are permitted to post their version of the article (e.g. in Word or Tex form) to their personal website or institutional repository. Authors requiring further information regarding Elsevier's archiving and manuscript policies are encouraged to visit:

http://www.elsevier.com/copyright 


\title{
Accessory protection structures in Glyptodon Owen (Xenarthra, Cingulata, Glyptodontidae)
}

\author{
Structures accessoires de protection en Glyptodon Owen \\ (Xenarthra, Cingulata, Glyptodontidae) \\ Alfredo Eduardo Zurita ${ }^{a}{ }^{*}$, Leopoldo Hector Soibelzon ${ }^{b}$, \\ Esteban Soibelzon ${ }^{\mathrm{b}}$, Germán Mariano Gasparini ${ }^{\mathrm{b}}$, \\ Marcos Martín Cenizo ${ }^{c}$, Héctor Arzani ${ }^{\mathrm{d}}$ \\ a Centro de Ecología Aplicada del Litoral (CECOAL-CONICET) y Universidad Nacional del Nordeste, \\ Ruta Prov. $N^{\circ} 5 \mathrm{Km} 2,5$ (3400), Corrientes, Argentina \\ b División Paleontología Vertebrados, Museo de La Plata, Facultad de Ciencias Naturales y Museo, \\ UNLP, Paseo del Bosque s/n (B1900FWA), La Plata, Argentina \\ c Área Paleontología, Fundación de Historia Natural Félix de Azara, Departamento de \\ Ciencias Naturales y Antropología, CEBBAD-UM, Valentín Virasoro 732 (C1405BDB) \\ Ciudad Autónoma de Buenos Aires, Buenos Aires, Argentina \\ d Museo de Ciencias Naturales "Carlos Ameghino”, 26 N $^{\circ} 512$ (B6600GXL), \\ Mercedes, Argentina
}

Received 21 May 2009; accepted 29 January 2010

Available online 19 March 2010

\begin{abstract}
The Glyptodontidae (Mammalia, Xenarthra) are one of the most common paleofaunistic elements in the South American megafauna. In this context, of the six genera most frequently recorded in the South American Pleistocene (Glyptodon, Neosclerocalyptus, Hoplophorus, Neuryurus, Panochthus and Doedicurus), at least four (Hoplophorus, Neuryurus, Panochthus and Doedicurus) present structures in their caudal armor that could have had defensive/offensive functions, in addition to a solid dorsal carapace and cephalic shield. In this article, we provide the first record and description of a series of highly modified osteoderms, located at the anterolateral region and over the cephalic notch of the dorsal carapace. These "spine"-like osteoderms were found in two of the largest Pleistocene glyptodonts: Glyptodon munizi (early-middle Pleistocene) and, G. reticulatus (late Pleistocene-early Holocene). We propose that they are structures for protection of the neck and abdomen, the most vulnerable body regions of these large armored animals, since they are not
\end{abstract}

\footnotetext{
* Corresponding author.

E-mail address: azurita@ cecoal.com.ar (A.E. Zurita).
} 
covered by the cephalic shield, carapace or caudal armor. Noteworthy, structures like those described herein are not known in glyptodonts recorded before the Great American Biotic Interchange (GABI), so it could be a reaction to the arrival of Smilodon and Arctotherium (Carnivora, Mammalia) the largest terrestrial carnivores that ever lived in South America.

(c) 2010 Elsevier Masson SAS. All rights reserved.

Keywords: Argentina; South America; Glyptodon; Pleistocene; Palaeoecology

\section{Résumé}

Les Glyptodontidae (Mammalia, Xenarthra) sont l'un des éléments paléofaunistiques les plus communs de la mégafaune en Amérique du Sud. Dans ce contexte, des six genres le plus souvent enregistrés dans le Pléistocène (Glyptodon, Neosclerocalyptus, Hoplophorus, Neuryurus, Panochthus et Doedicurus), au moins quatre (Hoplophorus, Neuryurus, Panochthus et Doedicurus) présentent dans leur armure caudale des structures qui auraient pu avoir des fonctions défensives/offensives, en plus d'une carapace dorsale solide et un bouclier céphalique. Dans cet article, nous proposons le premier enregistrement et la description d'une série d'ostéodermes très modifiés, situés dans la région antérolatérale et au-dessus de l'encoche céphalique de la carapace dorsale. Ces structures se rencontrent chez deux espèces du genre Glyptodon, l'une des plus grandes formes de Glyptodontidae du Pléistocène, G. munizi (Pléistocène inférieur et moyen), et G. reticulatus (Pléistocène supérieur - Holocène inférieur). D'un point de vue morphologique, ces ostéodermes montrent une forme caractéristique en «épine». Les ostéodermes décrits ici sont interprétés comme des structures de protection et de défense du cou et du ventre, régions les plus vulnérables de ces grands animaux à armure, car elles ne sont pas recouvertes par le bouclier céphalique, la carapace ou l'armure caudale. Enfin, il est intéressant de noter que ces types de structure ne sont pas enregistrés dans la paléofaune de Glyptodontidae qui vivaient avant le Great American Biotic Interchange (GABI), un processus migratoire qui marque l'arrivée de certains des plus grands prédateurs (Carnivora), ayant jamais vécu en Amérique du Sud (par exemple Smilodon, Arctotherium).

(C) 2010 Elsevier Masson SAS. Tous droits réservés.

Mots clés : Amérique du Sud ; Pléistocène ; Glyptodon ; Paléoécologie

\section{Introduction}

Glyptodonts (Glyptodontidae, Xenarthra) were frequent elements among the South American Cenozoic megaherbivores. Their wide fossil record ranges from the late Eocene to the earliest Holocene (Paula Couto, 1979).

During the Pleistocene ( $c a$. 2.6-0.011 Ma, see ICS, 2008) some glyptodonts reached body masses of, at least, $250 \mathrm{~kg}$ (e.g., Neosclerocalyptus), while others were well above $1000 \mathrm{~kg}$ (e.g., Panochthus intermedius; Glyptodon elongatus, Doedicurus clavicaudatus; see Fariña, 1995; Fariña and Vizcaíno, 1999).

Of the six genera that occur most frequently in the fossil record of South America (Glyptodon, Neosclerocalyptus, Hoplophorus, Neuryurus, Panochthus and Doedicurus; see Paula Couto, 1979), at least four (Hoplophorus, Neuryurus, Panochthus and Doedicurus) present structures in their caudal armor that could have had defensive/offensive functions (Fariña and Vizcaíno, 1999; Fariña, 2000). These structures located on the lateral sides of the caudal tube, representing remarkable cases of convergence, and consist of a series of depressions (two to five) with rough surface, which probably represents the area of insertion of conical spines (Hoffstetter, 1958). In some cases, (e.g., Doedicurus), the distal tip of the caudal tube is flattened forming a mace-like structure (see Lydekker, 1894: pl. XXVII). 
In other forms, such as Glyptodon (Glyptodontinae), the caudal armor comprises a series of rings with a very short tube at the distal tip. Each ring is formed by a double or triple row of osteoderms, of which the ones in the last row are conical (Ameghino, 1889; Soibelzon et al., 2006). This kind of conical osteoderms are also present at the margins of the dorsal carapace, and it quite probably represents a synapomorphy of the Glyptodontinae (Carlini and Scillato-Yané, 1999; Carlini et al., 2008).

In some Glyptodon specimens (e.g., MBM-PV 000778), a double or triple row of modified osteoderms may be observed at the anterolateral margin of the dorsal carapace; however, and unlike the specimens described here, these structures are part of the dorsal carapace (i.e., they are joined by synostoses) and their apices are conical-rounded.

In support of the postulated defensive/offensive function, it is worth noting that fractured dorsal armors have been found in some specimens (e.g., Doedicurus clavicaudatus MLP 16-94; Glyptodon reticulatus MACN 200), and these have been interpreted as the result of intraspecific combats (Alexander et al., 1999).

The occurrence of osteoderms on the ventral region of the Glyptodontidae was originally mentioned by Burmeister (1864). Later (Burmeister, 1870-1874), provided illustrations of these structures, particularly for the genera Panochthus and Glyptodon, suggesting that these glyptodonts could also have possessed osteoderms at the level ". . de la orilla anterior sobre las espaldas, de los pies o de las mejillas” (Burmeister, 1870-1874: 110). The presence of a continuous ventral plastron (as conceived by Burmeister) in the Glyptodontidae was seriously challenged by Ameghino (1889) and later by Castellanos (1940, 1941); however, Ameghino (1889) did recognize the presence of a series of "ossicles" within the dermis, but with no defined articulation among them.

Recently, Tauber and Di Ronco (2000) and Soibelzon et al. (2006) have positively confirmed the presence of osteoderms on the ventral and facial regions of Glyptodon reticulatus and G. munizi respectively, while Rinderknecht (2002) has reported similar elements in the hind limbs of Glyptodon. Unlike the ones described here, elements described by these authors have no defined shape, are small to medium-sized, and were probably completely embedded within the dermis (see Fig. 1C, D in Soibelzon et al., 2006).

In this context, the goals of our study are:

- to describe, for first time, those highly modified osteoderms, located on the anterolateral region and cephalic notch of the dorsal carapace in Glyptodon munizi and G. reticulatus;

- to advance paleobiological and paleoecological hypotheses regarding the appearance and function of these structures.

The chrono and biostratigraphic scheme adopted in this work follows Cione and Tonni (2005) and Soibelzon et al. (2008). The fossils presented here are from the Ensenadan (Mesotherium cristatum Biozone) and Bonaerian (Megatherium americanum Biozone) + Lujanian (Equus (A.) neogaeus Biozone.

Abbreviations: MLP, Museo de La Plata, División Paleontología Vertebrados, Facultad de Ciencias Naturales y Museo, Universidad Nacional de La Plata, Buenos Aires; MMP, Museo Municipal de Ciencias Naturales de Mar del Plata "Lorenzo Scaglia", Buenos Aires. MBM-PV, Museo Provincial de Ciencias Naturales "Bartolomé Mitre", Córdoba; MCA, Museo de Ciencias Naturales "Carlos Ameghino" (Mercedes, Buenos Aires). 


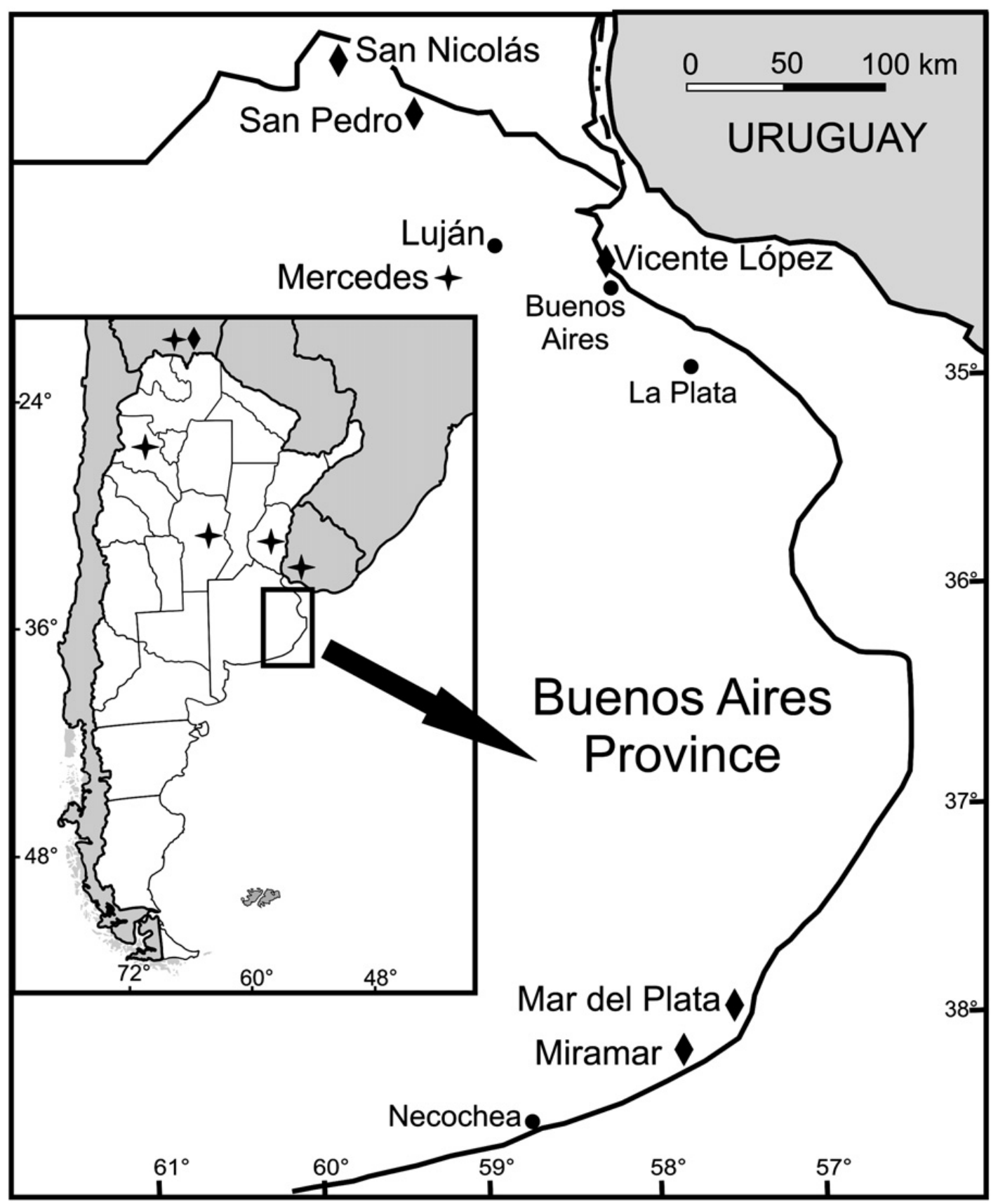

Fig. 1. Location map showing the localities mentioned in the text. Black stars show the provenance of Glyptodon reticulatus; black diamonds show the provenance of Glyptodon munizi; black circles represent cities of Buenos Aires Province as a location references.

Carte montrant l'emplacement des localités mentionnées dans le texte. Les étoiles noires montrent la provenance de Glyptodon reticulatus; les diamants noirs indiquent la provenance de Glyptodon munizi; les cercles noirs représentent les villes de la province de Buenos Aires comme des lieux de références.

\section{Systematic paleontology}

Order CINGULATA Illiger, 1811.

Family GLYPTODONTIDAE Gray, 1869.

Genus Glyptodon Owen, 1838.

Glyptodon munizi Ameghino, 1881. 
Holotype: MLP s/n (missing, Mones, 1986). Large portion of dorsal carapace from Arroyo del Medio, San Nicolás, Buenos Aires. Ensenadan (Ameghino, 1881).

Stratigraphic and geographical distribution: Ensenadan (lower to middle Pleistocene, see Soibelzon et al., 2008) of Argentina: Buenos Aires province (San Nicolás, San Pedro, Vicente López, Mar del Plata and Miramar; Soibelzon et al., 2006); Pleistocene of Bolivia: Tarija (Zurita et al., 2009) (Fig. 1).

Referred material MLP 07-V-3-2: (Fig. 2), large portion of a dorsal carapace and cephalic shield from the marine cliff at "Baliza Chica" (in front of Miramar Golf Club; $38^{\circ} 15^{\prime} 22.9^{\prime \prime} \mathrm{S}$ and $57^{\circ} 47^{\prime} 52.2^{\prime \prime} \mathrm{W}$ ), Miramar, General Alvarado County, Buenos Aires (Fig. 1). Ensenadan.

Stratigraphic remarks: At this locality, the base of the cliff is conformed by edaphized reddish loessic levels corresponding to Chapadmalal Fm. (Chapadmalalan, Neocavia depressidens Biozone, middle Pliocene) and the top by a relict sandy loess level corresponding to Lobería Fm. (Lujanian-Platan, Equus [A.] neogaeus-Lagostomus maximus biozone, late PleistoceneHolocene). The middle levels comprise facies of alluvial events represented by sandy silts with different degree of aquatic reworking. Among these, the level from where MLP 07-V-3-2 was exhumed comprises greenish-gray sandy clays probably originated in a restricted lentic water body. Middle and upper levels were referred to the "Ensenadan" by Ameghino (1908); later Kraglievich (1952) assigned them to his Vorohué Formation. This criterion has been maintained until present days. However, and in contrast with this traditional interpretation, the record of G. munizi, an exclusive Ensenadan taxon (see Cione and Tonni, 2005; Soibelzon et al., 2008) in the middle levels of this sector of the cliffs favoring the Ameghino's (1908) original idea about the age of these levels (see Soibelzon et al., 2009a,b). Additionally, a new record of Mesotherium cristatum (another exclusive Ensenadan taxon) comes from the same levels (Bogan, pers. com. to MMC). Outstandingly these records provide one of the few undisputable Ensenadan assignation to a cliff' level between Mar del Plata and Miramar.

\section{Description}

Dorsal carapace (Fig. 2): according to Soibelzon et al. (2006), G. munizi was a very large Glyptodontinae, larger than the Lujanian Glyptodontinae taxa. Its dorsal carapace is elongated, oblong-oval in shape, with thick and relatively small osteoderms that show central figures always larger than the peripheral ones. A central concavity occupies most of the osteoderm surface; it is especially evident in the carapace's periphery. The caudal armor is formed by nine rings, as in the other species of the genus.

Osteoderms are pentagonal with rough and punctuated dorsal surface that presents a welldefined subcircular central figure and a row of angular peripheral figures, following the characteristic Glyptodon morphology (Ameghino, 1889). The sulci that delimitate the central figure are deep and wide with parallel sides; this is a synapomorphy of the Glyptodontinae (Carlini et al., 2008). Distally, the central figure of each osteoderm becomes more noticeable with respect to the peripheral figures, which tend to be poorly developed or absent, condition common to all the Glyptodontidae that presents this "rosette" ornamentation pattern.

Osteoderms: On the ventral side of the dorsal carapace could be observed three rows of highly modified osteoderms running anteroposteriorly and conforming an almost flat plane obliquely oriented respect to the body sagittal plane (see Fig. 2[A, B]). Thus, the row of osteoderms in contact with the osteoderms of the carapace's peripherial row are conical with blunt apices; caudally, the osteoderms are taller, with a well-defined sharp tip that produce a "spine"-like appearance. The base of these osteoderms is quadrangular to subcircular (approximately $4.9 \mathrm{~mm}$ 


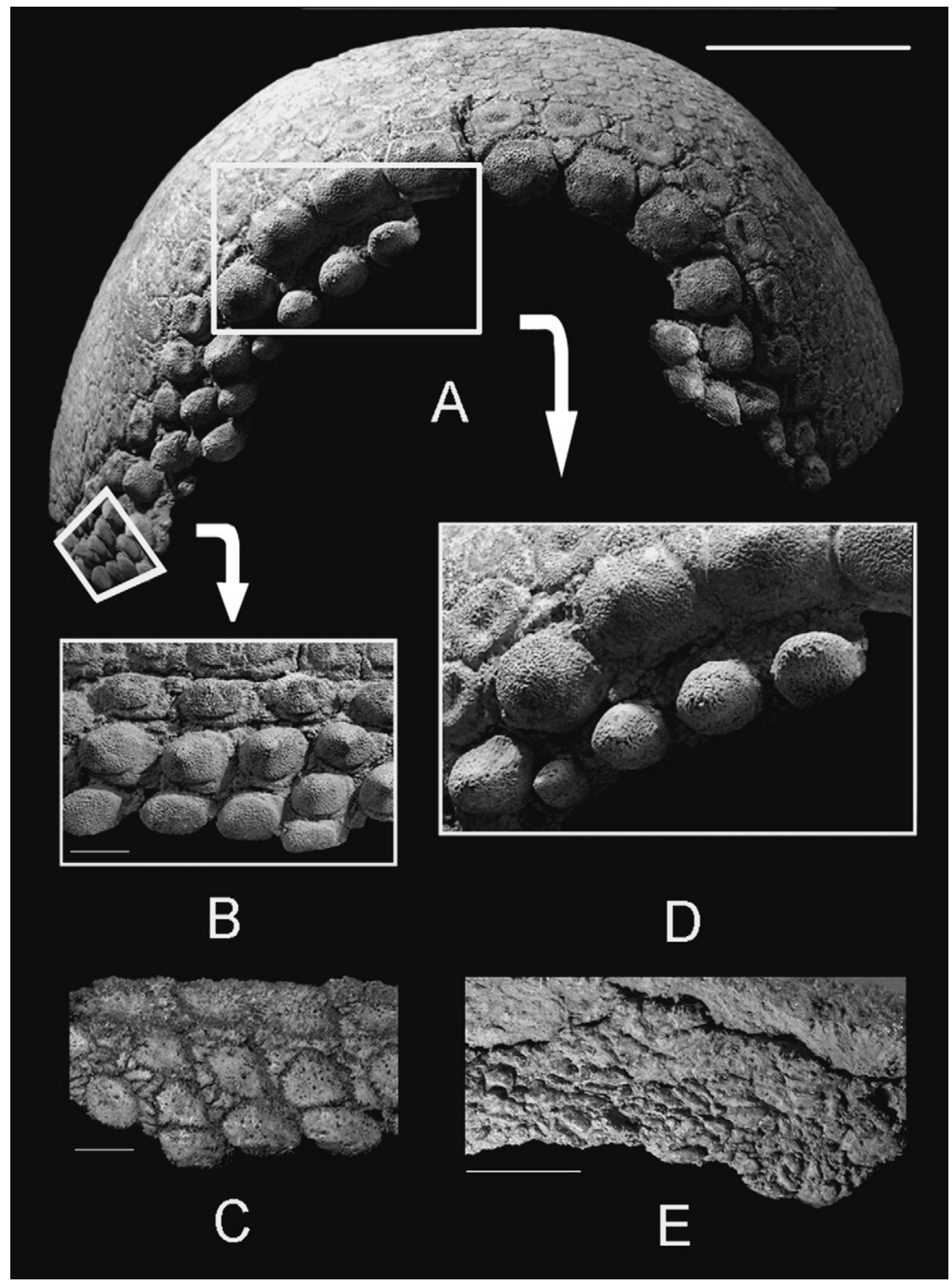

Fig. 2. Glyptodon munizi MLP 07-V-3-2. A. Dorsal carapace in anterior view. Scale bar $=25 \mathrm{~cm}$. B, C. Lateral osteoderms. Scale bar $=5 \mathrm{~cm}$. C. Inner view. D, E. Osteoderms of the cephalic notch. Scale bar $=5 \mathrm{~cm}$. D. Inner view. Glyptodon munizi MLP 07-V-3-2. A. Carapace dorsale en vue antérieure. Échelle $=25 \mathrm{~cm}$. B, C. Ostéodermes latérales. Échelle $=5 \mathrm{~cm}$. C. En vue interne. D, E. Ostéodermes de l'encoche céphalique. Échelle $=5 \mathrm{~cm}$. D. En vue interne. 
by $4.1 \mathrm{~mm}$ ) and is loosely sutured to adjacent osteoderms. The rows run toward the cephalic notch; in MLP 07-V-3-2 at least one of them is preserved. The space delimited by the vertices of the osteoderms is occupied by small amorphous osteoderms that are only visible on the inner surface of the carapace (Fig. 2[C]). These osteoderms are approximately $2.7 \mathrm{~mm}$ by $1 \mathrm{~mm}$ and somewhat similar to the facial osteoderms described for G. munizi by Soibelzon et al. (2006).

At the cephalic notch, there is one row of osteoderms with pointed apices, loosely articulated to the osteoderms of the carapace. Similar like the lateral osteoderms, the space between each osteoderm is occupied by smaller and oval osteoderms (see Fig. 2[D, E]).

Glyptodon reticulatus Owen, 1845.

Holotype: MACN 200, complete dorsal carapace. Lujanian (late Pleistocene-early Holocene). Argentina: Catamarca, Buenos Aires, Entre Ríos and Córdoba provinces (Ameghino, 1889; Duarte, 1997; Tauber and Di Ronco, 2000; Noriega et al., 2004); Uruguay (Ameghino, 1889). Pleistocene of Tarija (Bolivia) (see Takai et al., 1982; Zurita et al., 2009) (Fig. 1).

Referred material MCA 2015 and 2017: (Fig. 3), two dorsal carapaces with conical osteoderms at the level of the cephalic notch, loosely joined to the rest of the carapaces. From a quarry located $4 \mathrm{~km}$ from Mercedes city ( $34^{\circ} 38^{\prime} 34.03^{\prime \prime} \mathrm{S}$ and $59^{\circ} 18^{\prime} 4.38^{\prime \prime} \mathrm{W}$ ), Buenos Aires, Argentina. Luján Fm., Lujanian (late Pleistocene-early Holocene).

Description: According to Duarte (1997) in G. reticulatus, the cephalic opening is larger than the caudal one and both are semicircular. The osteoderms are quadrangular to hexagonal. The central figure is pentagonal to octagonal and flat or slightly convex. It is surrounded by seven quadrangular, pentagonal or hexagonal peripheral figures separated by deep and wide sulci. Four or five perforations (ranging from small to large size) appear at the intersection of the radial sulci (developed between peripheral figures) and the central sulcus (that runs around the central figure). It is especially evident at the central-medial sector of the carapace. The dorsal carapace shows the clearly convex dorsal outline characteristic of this species (see Ameghino, 1889).

Specimens MCA 2015 and 2017 present on the dorsal carapace, especially at the cephalic notch, peculiar structures like to those described on MLP 07-V-3-2 (Fig. 3). At this notch, there is a double accessory row of extremely modified osteoderms with pointed apices, as in MLP 07-V-3-2, loosely articulated to carapace osteoderms. Each row is formed by approximately 14 osteoderms, whereas the cranial row is composed by smaller osteoderms, and each of them are located between two osteoderms of the caudal row (see Fig. 3).

\section{Paleoecological context}

Before Pleistocene (i.e., late Miocene of Catamarca province and Pliocene of the Pampean region), there are no records of Glyptodontinae specimens with osteoderms like those described here. In addition, Glyptodonts recorded before GABI (e.g., Paraglyptodon uquiensis from late Pliocene of Jujuy province, Argentina) are smaller than those recorded after this event (e.g., Glyptodon munizi; see Soibelzon et al., 2006). Noteworthy, the first records of osteoderms (apart from those conforming the dorsal carapaces, cephalic shield and caudal armors; see Tauber and Di Ronco, 2000; Rinderknecht, 2002; Soibelzon et al., 2006), as well as those described here, are coincident to the arrival of the large predators from North America. Notably, these highly modified osteoderms have not been observed in North American glyptodonts (see Gillette and Ray, 1981).

Gillette and Ray (1981) have reported for Glyptotherium texanum the finding of a specimen with evidences of having been attacked by a large-sized predator; in South America, Prevosti and Palmqvist (2001) have postulated that the canid Theriodictis platensis could have preyed upon some Pleistocene Glyptodontidae (e.g., Neosclerocalyptus). 


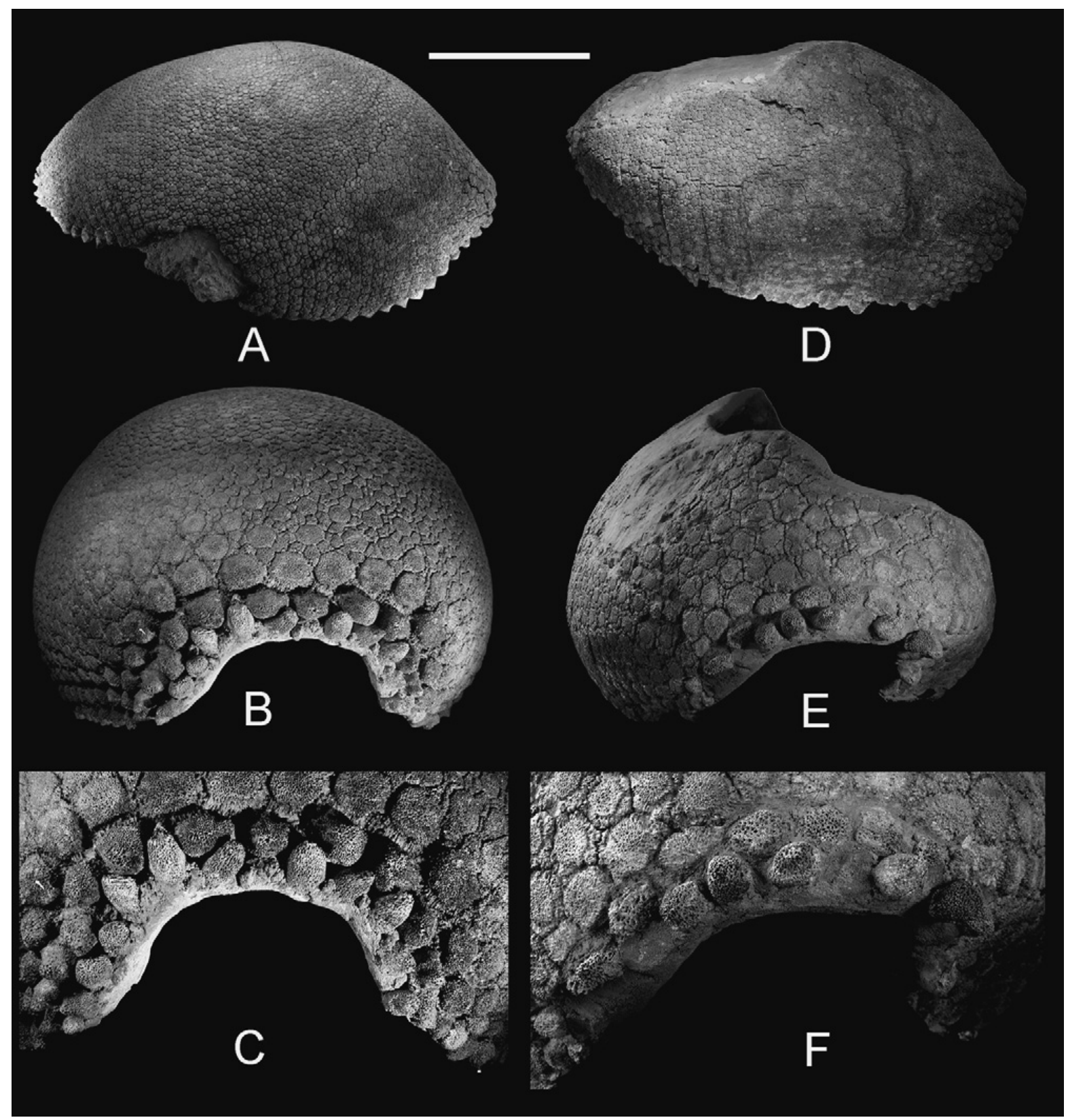

Fig. 3. Glyptodon reticulatus. A-C. MCA 2015. D-F. MCA 2017. A, D. Dorsal carapace in lateral view. B, E. Dorsal carapace in anterior view. C, F. Osteoderms of the cephalic notch. Scale bar $=50 \mathrm{~cm}$.

Glyptodon reticulatus. A-C: MCA 2015; D-F: MCA 2017. A, D : carapace dorsale en vue latérale; B, E: carapace dorsale en vue antérieure; $\mathbf{C}, \mathbf{F}$ : ostéodermes de l'encoche céphalique. Échelle $=50 \mathrm{~cm}$.

In this context, Soibelzon et al. (2009b) suggested that the arrival in South American of large carnivores (e.g., Arctotherium angustidens, (Gervais and Ameghino) Ursidae and Smilodon populator, (Lund) Felidae) during Ensenadan, could have triggered some adaptative responses among native mammalian fauna, since large carnivores were absent of South America during most of the Cenozoic. Only the medium-sized carnivore Thylacosmilus Riggs (marsupial saber tooth cat), together with small carnivorous marsupials (Thylophorops and Hyperdidelphis), omnivorous procyonids (Cyonasua Ameghino and Chapadmalania Ameghino) and phororhacoid birds were present before GABI. After the Plio-Pleistocene boundary (subsequent to GABI), the top predator guild in the South America Ensenadan ecosystems included seven species: Theriodictis platensis Mercerat, Protocyon scagliorum Kraglievich, P. troglodytes (Lund) and Canis (?) 


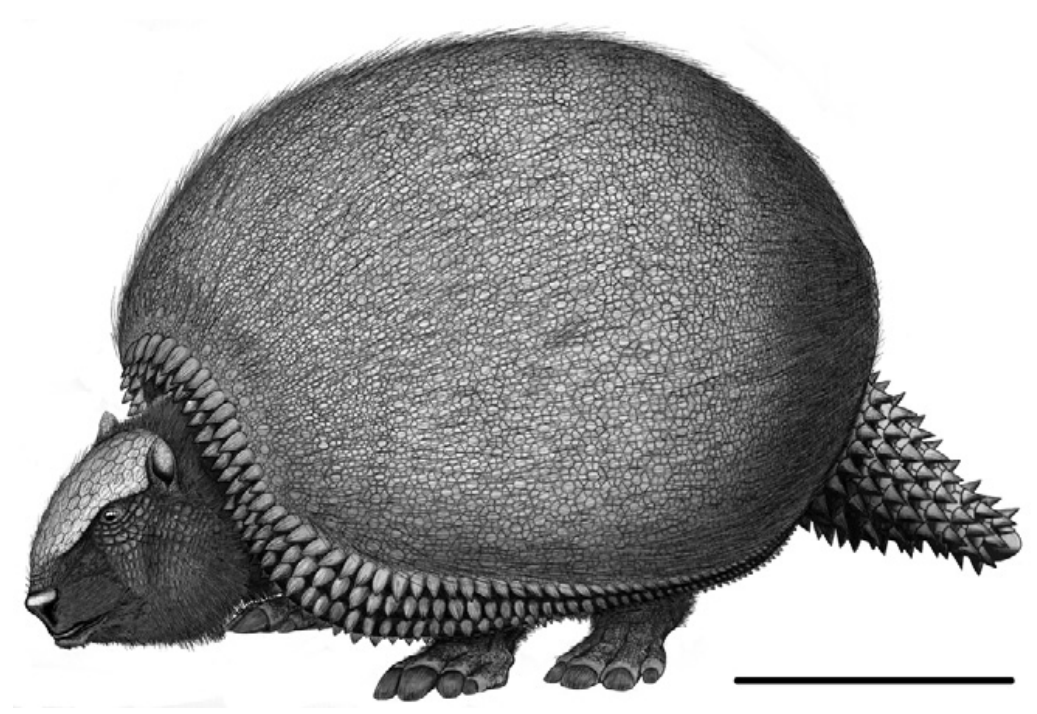

Fig. 4. Reconstruction of Glyptodon. Scale bar $=100 \mathrm{~cm}$. Reconstruction de Glyptodon. Échelle $=100 \mathrm{~cm}$.

gezi Kraglievich (Canidae: Prevosti, 2007), Smilodon populator, Panthera onca (Linnaeus) and Puma Jardine (Felidae: Soibelzon and Prevosti, 2007), and Arctotherium angustidens (Ursidae, Soibelzon, 2004; Soibelzon et al., 2005) (see Webb, 2006).

The fast diversification of carnivore guild possibly led to the evolution of different strategies (e.g., behavioral, physiological, anatomical) in the potential prey (Soibelzon et al., 2009b).

\section{Discussion and conclusions}

The presence of isolated osteoderms and included in the dermis, lacking defined articulation, were confirmed in Glyptodon (see Tauber and Di Ronco, 2000; Rinderknecht, 2002; Soibelzon et al., 2006). These findings partially supports the Burmeister (1874) and Ameghino (1889) hypothesis. Since these osteoderms are not firmly attached to the rest of the shield, it is not surprising the high amount of specimens without them.

The structures described here could represent selected features favored by the presence of the newly arrived carnivores in order to protect vulnerable areas of these armored xenarthrans: the neck and abdomen. We suggest that these modified osteoderms could have had a horny sheath that almost certainly made their apices even more pointed and increased their efficiency (Fig. 4). Thus, the description of Pleistocene Glyptodontinae is updated with the addition of new structures.

\section{Acknowledgements}

The authors wish to thank to E.P Tonni for revising a preliminary version of this manuscript; Leonel Acosta, Juan J. Molly and Darío Fernández for the preparation of specimen; also thanks to Anahí Mainetti for field work collaboration; and Cecilia Morgan for the English translation. This work was partially covered by ANPCYT, UNLP and CONICET.

\section{References}

Alexander, R.M., Fariña, R., Vizcaíno, S.F., 1999. Tail blow energy carapace fractures in a large glyptodont (Mammalia Xenarthra). Zoological Journal of the Linnean Society 126, 41-49. 
Ameghino, F., 1881. La antigüedad del hombre en el Plata, 2. Buenos Aires, Masson, Paris and Igon Hermanos.

Ameghino, F., 1889. Contribución al conocimiento de los mamíferos fósiles de la República Argentina. Actas de la Academia Nacional de Ciencias de Córdoba 6, 1-1027.

Ameghino, F., 1908. Las formaciones sedimentarias de la región Litoral de Mar del Plata y Chapalmalal. Anales del Museo Nacional de Buenos Aires 3 (10), 343-428.

Burmeister, G., 1864. Noticias preliminares sobre las diferentes especies de Glyptodon en el Museo Público de Buenos Aires 1 (1), 71-85.

Burmeister, G., 1870-1874. Monografía de los Glyptodontes en el Museo Público de Buenos Aires. Anales del Museo Público de Buenos Aires 2, 1-412.

Carlini, A.A., Scillato-Yané, G.J., 1999. Evolution of Quaternary Xenarthrans (Mammalia) of Argentina. In: Rabassa, J., Salemme, M. (Eds.), Quaternary of South America and Antarctic Peninsula 12, pp. 149-175.

Carlini, A.A., Zurita, A.E., Scillato-Yané, G.J., Sánchez, M., Aguilera, O., 2008. New Glyptodont from Codore Formation (Pliocene), Falcón State Venezuela, its relationship with the Asterostemma problem and the palaeobiogeography of the Glyptodontinae. Paläontologische Zeitschrift 82, 125-138.

Castellanos, A., 1940. A propósito de los géneros Plohophorus Nopachthus y Panochthus. Publicaciones del Instituto de Fisiografía y Geología 1 (6), 1-279.

Castellanos, A., 1941. A propósito de los géneros Plohophorus Nopachthus y Panochthus. Publicaciones del Instituto de Fisiografía y Geología 2 (8), 279-418.

Cione, A.L., Tonni, E.P., 2005. Bioestratigrafía basada en mamíferos del Cenozoico superior de la provincia de Buenos Aires, Argentina. $16^{\circ}$ Congreso Geológico Argentino, Relatorio, La Plata, 183-200.

Duarte, R.G., 1997. Gliptodontes del Pleistoceno tardío de Aguas de Las Palomas, campo del Pucará, Catamarca, Argentina. Variaciones morfológicas del caparazón de Glyptodon reticulatus Owen, 1845. Ameghiniana 34, 345-355.

Fariña, R., 1995. Limb bone strength and habits in large glyptodonts. Lethaia 28, 189-196.

Fariña, R., 2000. Física y matemáticas para reconstruir la vida en el pasado. Actas de Fisiología 6, 45-70.

Fariña, R., Vizcaíno, S.F., 1999. A century after Florentino Ameghino: the palaeobiology of the Quaternary Land Mammal fauna of South America. In: Rabassa, J., Salemme, M. (Eds.), Quaternary of South America and Antarctic Peninsula 12, pp. 255-277.

Gillette, D.D., Ray, C.E., 1981. Glyptodonts of North America. Smithsonian Contributions to Paleobiology 40, 1-251.

Hoffstetter, R., 1958. Xenarthra. In: Piveteau, J. (Ed.), Traité de Paléontologie (6) 2. Masson, Paris, pp. 535-636.

ICS (International Commission on Stratigraphy), 2008. International Stratigraphic Chart. In: Ogg, J.G., Ogg, G., Gradstein, F.M. (Eds.), A Concise Geologic Timescale. Cambridge University Press, Cambridge.

Kraglievich, J.L., 1952. El perfil geológico de Chapadmalal y Miramar Provincia de Buenos Aires. Revista del Museo Municipal Ciencias Naturales y Tradicional de Mar del Plata 1, 8-37.

Lydekker, R., 1894. Contribution to knowledge of the fossil vertebrates of Argentina 2. The extinct Edentates of Argentina. Anales del Museo de La Plata (Paleontología) 3, 1-118.

Mones, A., 1986. Paleovertebrata Sudamericana. Catálogo sistemático de los vertebrados fósiles de América del Sur. Parte I. Lista preliminar y Bibliografía. Courier Forschungsinstitut Senckenberg 82, 1-625.

Noriega, J.I., Carlini, A.A., Tonni, E.P., 2004. Vertebrados del Pleistoceno tardío de la cuenca del arroyo Ensenada (Departamento Diamante, provincia de Entre Ríos, Argentina). Revista del Instituto Superior de Correlación Geológica (Misceláneas) 12, 71-76.

Owen, R., 1845. Descriptive and illustrated catalogue of the fossil organic remains of Mammalia and Aves contained in the Museum of the Royal College of Surgeons of England. R. and J.E. Taylor, London.

Paula Couto, C., 1979. Tratado de Paleomastozoología. Academia Brasileira de Ciências, Rio de Janeiro.

Prevosti, F.J., 2007. Grandes cánidos (Carnivora, Canidae) del Cuaternario de la República Argentina: sistemática, filogenia, bioestratigrafía y paleoecología. Tesis Doctoral Facultad de Ciencias Naturales y Museo. Universidad Nacional de La Plata (inédita).

Prevosti, F.J., Palmqvist, P., 2001. Análisis ecomorfológico del cánido hipercarnívoro Theriodictis platensis Mercerat (Mammalia Carnívora) basado en un nuevo ejemplar del Pleistoceno de Argentina. Ameghiniana 38, 375-384.

Rinderknecht, A., 2002. La presencia de osteodermos en las extremidades posteriores de Glyptodon clavipes Owen, 1839 (Mammalia: Cingulata). Ameghiniana 37, 369-373.

Soibelzon, L.H., 2004. Revisión sistemática de los Tremarctinae (Carnivora Ursidae) fósiles de América del sur. Revista del Museo Argentino de Ciencias Naturales 6, 107-133.

Soibelzon, E., Cenizo, M.M., Soibelzon, L.H., Tonni, E.P., 2009a. Actualización faunística de las secuencias costeras del Plioceno y Pleistoceno en el partido de General Alvarado, provincia de Buenos Aires Nuevas interpretaciones bioestratigráficas. 24 Jornadas Argentinas de Paleontología de Vertebrados, resúmenes, 56-57. 
Soibelzon, L.H., Pomi, L.M., Tonni, E.P., Rodríguez, S., Dondas, A., 2009b. First Report of a Short-Faced Bears' den (Arctotherium angustidens) Palaeobiological and Palaeoecological implications. Alcheringa 33, 211-222.

Soibelzon, L.H., Prevosti, F.J., 2007. Los carnívoros (Carnivora, Mammalia) terrestres del Cuaternario de América del Sur. In: Pons, G.X., Vicens, D. (Eds.), Geomorfología Litoral i Quaternari. Homenatge a Joan Cuerda Barceló. Monografie del Societat d'Història Natural 14, Palma de Mallorca, pp. 49-68.

Soibelzon, E., Tonni, E.P., Bidegain, J.C., 2008. Cronología, magnetoestratigrafía y caracterización bioestratigráfica del Ensenadense (Pleistoceno inferior-medio) en la ciudad de Buenos Aires. Revista de la Asociación Geológica Argentina 63, 421-429.

Soibelzon, L.H., Tonni, E.P., Bond, M., 2005. The fossil record of South American short-faced bears (Ursidae, Tremarctinae). Journal of South American Earth Sciences 20, 105-113.

Soibelzon, E., Zurita, A.E., Carlini, A.A., 2006. Glyptodon munizi Ameghino (Mammalia, Cingulata Glyptodontidae): redescripción y anatomía. Ameghiniana 43, 377-384.

Takai, F., Mizuno, T., Iwasaki, K., Tanaka, K., Yoshida, A., 1982. Tarija mammal-bearing Formation in Bolivia. The Research Institute of Evolutionary Biology Tokyo 3, 1-72.

Tauber, A.A., Di Ronco, J., 2000. Nuevo hallazgo de placas ventrales de Glyptodon Owen, 1839 (Mammalia, Cingulata Glyptodontidae) en la provincia de Córdoba, República Argentina. Boletín de la Academia Nacional de Ciencias 64, 336-347.

Webb, S.D., 2006. The Great American Biotic Interchange: Patterns and Processes. Annals of the Missouri Botanical Garden 93, 245-257.

Zurita, A.E., Miño Boilini, A.R., Soibelzon, E., Carlini, A.A., Paredes Ríos, F., 2009. The diversity of (Xenarthra) in the Tarija valley (Bolivia): systematic, biostratigraphic and paleobiogeographic aspects of a particular assemblage. Neues Jahrbuch für Geologie und Paläontologie-Abhandlungen 251/252, 225-237. 